\title{
RANCANG BANGUN APLIKASI INFORMASI HARGA PRODUK PANGAN DAN SEMBAKO DI PASAR KAB. KARAWANG
}

\author{
${ }^{1}$ April Lia Hananto, ${ }^{2}$ Bayu Priyatna \\ 1,2 Universitas Buana Perjuangan Karawang, Sistem Informasi \\ 1 aprilia@ubpkarawang.ac.id \\ 2 bayu.priyatna20@gmail.com \\ 1,2 Jl. H. S. Ronggowaluyo Telukjambe Timur Karawang 41361
}

\begin{abstract}
Pesatnya perkembangan teknologi informasi dan komunikasi atau yang dikenal dengan istilah Information and Communication Technology (ICT), saat ini semakin merambah ke-berbagai bidang kehidupan masyarakat tidak terkecuali bidang ketahanan pangan. Dari sisi yang berbeda dapat dilihat bahwa dengan adanya ICT bagaimana suatu proses transfer informasi dapat dilakukan kapan saja tanpa adanya batasan ruang dan waktu. Pasar merupakan kegiatan ekonomi masyarakat, hal ini didasari atau didorong faktor perkembangan ekonomi yang pada awalnya hanya bersumber pada problem untuk memenuhi kebutuhan hidup manusia (kebutuhan pokok). Produk yang dapat kita temukan di pasar salah satunya adalah produk pangan khususnya sembilan bahan pokok (SEMBAKO), sembako adalah kebutuhan pokok masyarakat kita, dan merupakan komoditi utama sebagai acuan kesejahteraan masyarakat. Tujuan penelitian ini adalah : a) Dapat mengumpulkan sumber data harga yang valid dari relawan pedagang dan stakeholder untuk diinformasikan kepada masyarakat. b)Dapat membangun aplikasi informasi harga produk pangan dan berbasis Mobile yang dapat berjalan di Sistem Operasi Android. Dalam menentukan harga digunakan suatu metode perhitungan, menurut Marcelina Rizka Falevy dkk (2012),[5] Simple Moving Average atau juga disingkat SMA adalah Moving Average paling sederhana dan tidak menggunakan pembobotannya dalam perhitungan terhadap pergerakan closing price. Meskipun sederhana, SMA cukup efektif dalam menentukan trend yang sedang terjadi di market. Cara pembacaannya pun sederhana.
\end{abstract}

\section{Keywords: ICT, pasar, produk pangan dan sembako, Mobile, Android,Moving Average.}

\section{Latar Belakang}

Pesatnya perkembangan teknologi informasi dan komunikasi atau yang dikenal dengan istilah Information and Communication Technology (ICT), saat ini semakin merambah ke-berbagai bidang kehidupan masyarakat tidak terkecuali bidang ketahanan pangan. Dari sisi yang berbeda dapat dilihat bahwa dengan adanya ICT bagaimana suatu proses transfer informasi dapat dilakukan kapan saja tanpa adanya batasan ruang dan waktu.

Media yang serig digunakan untuk memperoleh informasi salah satunya adalah internet, dengan internet semua informasi yang dibutuhkan dapat diperoleh dengan cepat dan mudah. Menurut lembaga riset pasar e-Marketer, populasi netter di indonesia pada tahun 2014 mencapai 83,7 juta orang dan 93,4 juta orang pada tahun 2015, saat ini Indonesia berada pada peringkat ke- 6 terbesar di dunia dalam hal jumlah pengguna internet.

Pasar merupakan kegiatan ekonomi masyarakat, hal ini didasari atau didorong faktor perkembangan ekonomi yang pada awalnya hanya bersumber pada problem untuk memenuhi kebutuhan hidup manusia (kebutuhan pokok). Pasar selama ini sudah menyatu dan memiliki tempat yang paling penting dalam kehidupan masyarakat sehari-hari, secara garis besar pasar adalah tempat bertemunya penjual dan pembeli.

Produk yang dapat kita temukan di pasar salah satunya adalah produk pangan khususnya sembilan bahan pokok (SEMBAKO), sembako adalah kebutuhan pokok masyarakat kita, dan merupakan komoditi utama sebagai acuan kesejahteraan masyarakat, tetapi sayangnya di tingkat masyarakat kelas menengah kebawah sering terjadi spikulasi harga bahan pangan dikarenakan kurangya informasi yang akurat tentang perkembangan harga yang berlaku pada saat itu. Permasalahan tersebut tidak jarang dimanfaatkan oleh para oknum pedagang yang nakal khususnya pedagang di pasar tradisional dengan menaikan harga yang bukan semestinya.

Dari uraian tersebut terbentuklah suatu pemikiran yang sifatnya ingin membantu mengatasi permasalahan tersebut dengan merancang dan mebangun aplikasi informasi harga produk pangan dan sembako di pasar. 


\section{Tinjauan Pustaka}

\section{A. Rancang Bangun Aplikasi}

System menurut Menurut Jogiyanto (2005). Rancang Bangun (desain) adalah tahap dari setelah analisis dari siklus pengembangan sistem yang merupakan pendefinisian dari kebutuhan-kebutuhan fungsional, serta menggambarkan bagaimana suatu sistem dibentuk yang dapat berupa penggambaran, perencanaan dan pembuatan sketsa atau pengaturan dari beberapa elemen yang terpisah ke dalam satu kesatuan yang utuh dan berfungsi, termasuk menyangkut mengkonfigurasikan dari komponen-komponen perangkat keras dan perangkat lunak dari suatu sistem. [12]

Janner Simarmata (2010). Aplikasi atau perangkat lunak menurut Janner Simarmata adalah instruksi langsung komputer untuk melakukan pekerjaan dan dapat ditemukan di setiap aspek kehidupan modern, seperti perangkat pemantauan medis dan pembangkit tenaga listrik sampai perangkat hiburan, seperti video dan game. [4]

\section{B. Pengertian Pasar}

Menurut Utami Dewi dan F. Winarni (2014), pasar merupakan tempat dimana sekelompok perusahaan (penjual) bertemu dengan sekelompok pembeli untuk melakukan transaksi jual beli barang atau jasa.

Ada lima fungsi pasar, yaitu :

1. Menetapkan nilai (sets value)

2. Pendistribusi barang

3. Pengorganisir produksi

4. Penyelenggara penjatahan (rationing)

5. Mempertahankan dan mempersiapkan kebutuhan di masa depan.[10]

\section{Pasar Tradisional}

Menurut Utami Dewi dan F. Winarni (2014), pasar tradisional merupakan pasar yang dikelola dengan manajemen yang lebih tradisional dan simpel daripada pasar modern. Pasar tradisional cenderung menjual barangbarang lokal dan kurang ditemui barang impor. Dari segi harga, pasar tradisional tidak memiliki label harga yang pasti karena harga disesuaikan dengan besarnya keuntungan yang diinginkan oleh setiap pemilik usaha sendiri-sendiri.[10]

\section{E. Produk Pangan dan Sembako}

Menurut Eddy Afrianto, dkk (2008), Bahan pangan adalah bahan yang digunakan untuk menghasilkan pangan. Sedangkan produk pangan adalah hasil penanganan atau pengolahan bahan pangan.[2] Menurut Marcelina Rizka Falevy dkk (2012), Sembilan Bahan Pokok (SEMBAKO) adalah kebutuhan pokok masyarakat kita, dan merupakan komoditi utama sebagai acuan kesejahteraan masyarakat. [5]

Berikut adalah jenis-jenis sembako :

1. Beras, Sagu dan Jagung

2. Gula pasir

3. Sayur-sayuran dan Buah-buahan

4. Daging Sapi, Ayam, dan Ikan

5. Minyak goreng dan Margarin

6. Susu

7. Telur

8. Minyak Tanah atau gas ELPIJI

9. Garam berIodium dan berNatrium

\section{F. Pengertian Internet}

Internet menurut M. Shalahuddin dan Rosa A.S (2010:3). adalah sekumpulan jaringan berbeda yang saling terhubung bersama sebagai satu kesatuan dengan menggunakan berbagai macam protocol, salah satunya adalah protocol TCP/IP (Transmission control protocol/internet protocol). Internet memiliki layanan-layanan (services) yang telah banyak digunakan pada saat ini, layanan-layanan (services) internet diantaranya adalah :

1. Layanan informasi dengan menggunakan Worl Wide Web/WWW menggunakan protocol HTTP (Hypertext Transfer Protocol).

2. Layanan e-mail dengan menggunakan protocol POP (Post Office Protocol), SMTP (Simple Mail Transfer Protocol). 
3. Layanan chatting dengan menggunakan IRC (Internet Relat Chat).

4. Layanan pertukaran file dengan menggunakan FTP (File Transfer Protocol).

5. Layanan akses komputer jarak jauh (telnet).

6. Layanan akses direktori dengan menggunakan LDAP (Lightweight Directory Acces Protocol).

7. Layanan monitoring jaringan dengan menggunakan NMAP (National Maternity Action Plan).

8. Layanan pengiriman modul aplikasi dengan menggunakan SOAP (Simple Object Acces Protocol).

9. Layanan pengiriman suara dengan menggunakan VOIP (Voice over IP).[6]

\section{G. Rekayasa Perangkat Lunak}

Rekayasa perangkat lunak menurut Murya Arief Basuki (2009), adalah disiplin ilmu rekayasa atau teknik yang berkaitan dengan semua aspek dalam membuat perangkat lunak yang mengharuskan mengikuti pendekatan yang sistematis dan teratur dan menggunakan alat dan teknik yang cocok sesuai dengan masalah yang akan dipecahkan, batasan pembangunan dan sesumber yang tersedia. [7]

\section{H. System Development Life Cycle (SDLC)}

Menurut Al-Bahra Bin Ladjamudin (2005:38), System Development Life Cycle adalah daur hidup pengembangan system yang berfungsi untuk menggambarkan tahapan-tahapan utama dan langkah-langkah dari setiap tahapan yang secara garis besar terbagi dalam tiga kegiatan utama, yaitu :
1. Analysis
2. Design
3. Implementation.[1]

\section{System Development Life Cycle (SDLC)}

Menurut Wahyu Lukman Hakim (2011). Untuk me-modelkan sebuah perangkat lunak, metode prototyping memiliki tahapan-tahapan didalam proses pengembangannya. Tahapan inilah yang menentukan keberhasilan dari sebuah software. Pengembang perangkat lunak harus memperhatikan tahapan dalam metode prototyping agar aplikasi dapat diterima oleh pemakai.[11], berikut adalah gambar tahapan prototyping:

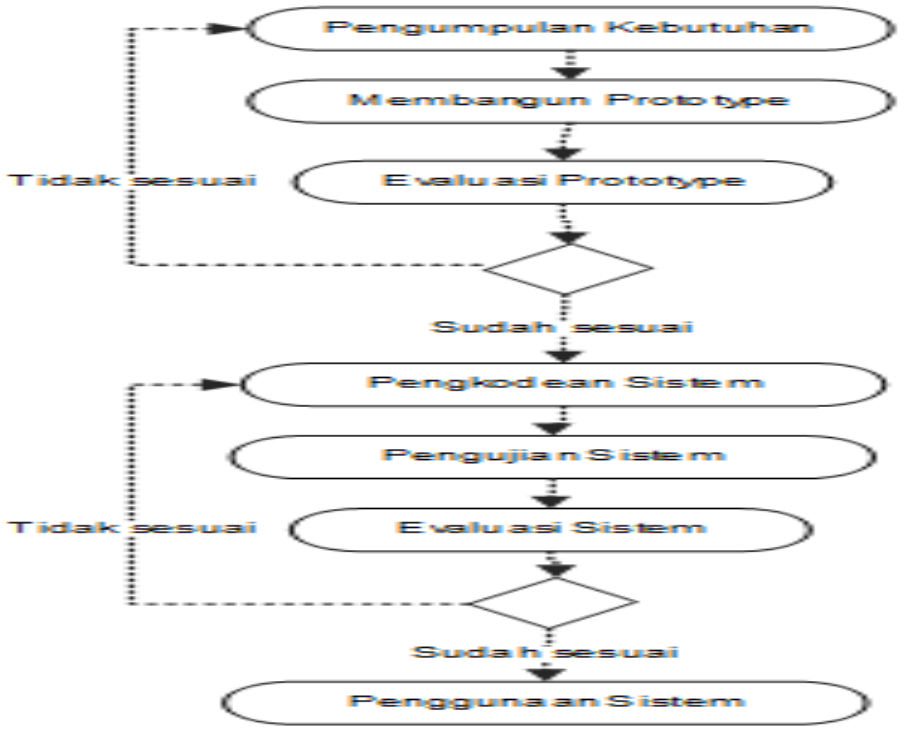

Gambar 2.1. Tahapan model prototype

\section{J. Perangkat Mobile}

Menurut Gilbran Imami (2015), perangkat mobile memiliki kapabilitas yang cukup untuk menjalankan aplikasiaplikasi yang berkaitan dengan produktivitas kerja. Bentuk perangkat mobile relatif mudah dibawa ke mana saja dan diakses kapan saja, selain itu kebutuhan untuk mengakses informasi dengan cepat yang dimungkinkan dengan kemampuan komunik.[3] 


\section{K. Android}

Android Menurut Nazruddin Safaat H. (2012.p.1), me-rupakan sebuah sistem operasi untuk perangkat lunak mobile berbasis linux yang mencangkup sistem operasi, middlewere dan aplikasi. Android juga menyediakan sebuah platform terbuka bagi para pengembang untuk menciptakan sebuah aplikasi. Pada awalnya Google Inc. membeli Android Inc. yang merupakan pendatang baru dari pembuatan peranti lunak untuk ponsel/ smartphone. Saat perilisan perdana Android, 5 November 2007, Android bersama Open Handset Alliace menyatakan mendukung pengembangan open source pada perangkat mobile. Sedangkan di lain pihak, Google merilis kode-kode Android dibawah lisensi Apache, yang merupakan lisensi perangkat lunak dan open platform perangkat seluler.[8]

\section{Basis Data}

Menurut Suparto Darudiato dkk (2006), basis data sebagai kumpulan data yang terorganisasi dan saling berhubungan. Terorganisasi maksudnya adalah data yang terstruktur sehingga mudah disimpan, dimanipulasi, dan diambil kembali oleh pengguna. Saling berhubungan maksudnya adalah data menggambarkan suatu domain yang menjadi perhatian sekelompok pengguna dan pengguna-pengguna dapat me-nggunakan data untuk menjawab pertanyaan yang menjadi perhatian dari domain tersebut.[9]

\section{Simple Moving Average}

Dalam menentukan harga digunakan suatu metode per-hitungan, menurut Marcelina Rizka Falevy dkk (2012), Simple Moving Average atau juga disingkat SMA adalah Moving Average paling sederhana dan tidak menggunakan pembobotannya dalam perhitungan terhadap pergerakan closing price. Meskipun sederhana, SMA cukup efektif dalam menentukan trend yang sedang terjadi di market. Cara pembacaannya pun sederhana. Perumusan yang digunakan dalam SMA adalah sebagai berikut:

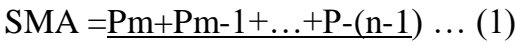

$\mathrm{n}$

Ket:

$\mathrm{n}=$ periode

$\mathrm{Pm}=$ harga periode $1 .[5]$

\section{METOE PENELITIAN}

Metode yang digunakan yaitu metode rekayasa dengan menggunakan Software Development Life Cycle (SDLC) dalam pengembangan aplikasinya menggunakan model prototype. Alasan penelitian menggunakan model prototype ini karena model ini memberikan pendekatan yang terbaik jika mendefinisikan aturan-aturan main pada saat awal yaitu pelanggan dan pengembang keduanya harus setuju bahwa prototype dibangun untuk berfungsi sebagai mekanisme pendefinisian kebutuhan. Lokasi penelitian di Laboratorium Komputer UBP Karawang.

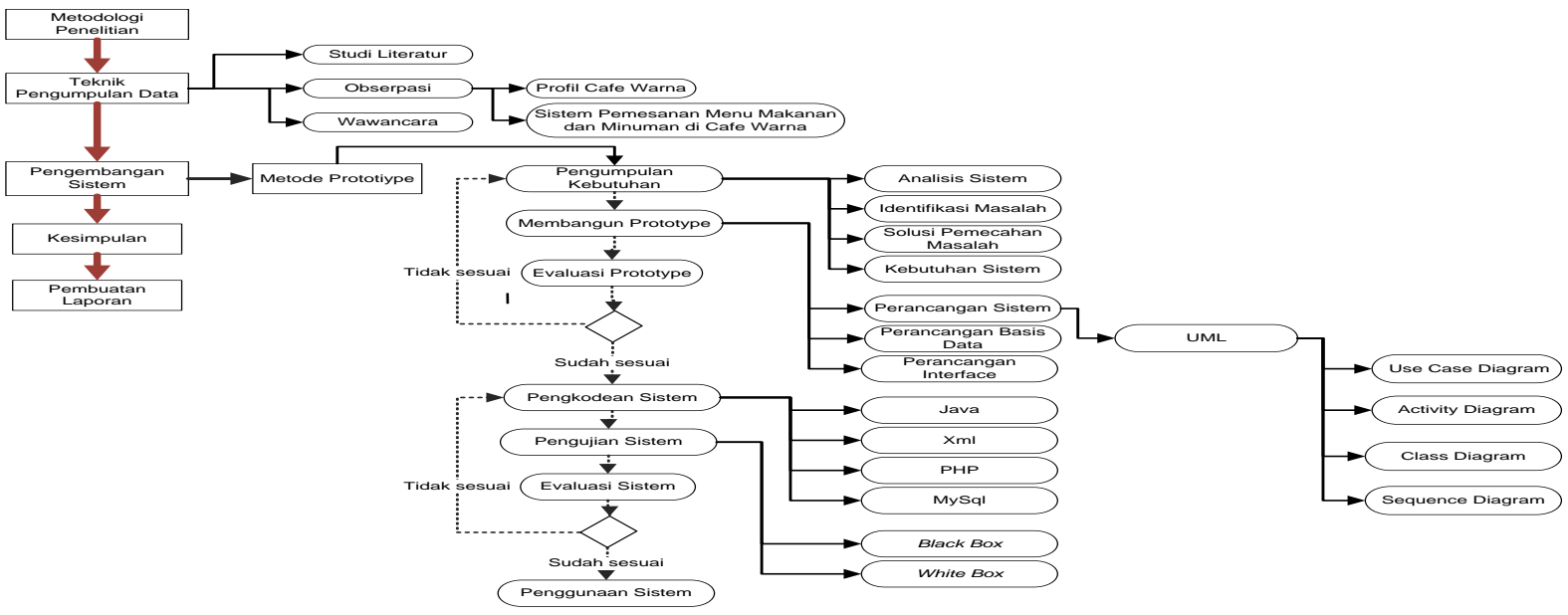

Gambar 3.1 Tahapan Metodologi Penelitian 
Model prototype ini memberikan pendekatan yang terbaik jika mendefinisikan aturan-aturan main pada saat awal yaitu pelanggan dan pengembang keduanya harus setuju bahwa prototype dibangun untuk berfungsi sebagai mekanisme pendefinisian kebutuhan.

Metode prototype yang diusulkan dibagi menjadi sejumlah aktifitas kerja, disebut wilayah tugas yang terbagi menjadi tujuh wilayah tugas sebagai :

\section{A. Teknik Pengumpulan Data}

Teknik pengumpulan data untuk mendapatkan data sekunder dan data primer, diantaranya adalah :

a. Studi literature

Studi literature adalah sebuah teknik untuk mendapatkan data sekunder dengan cara membaca buku-buku, jurnal, paper dan lainnya.

b. Wawancara

Wawancara adalah teknik pengumpulan data primer dengan secara langsung tatap muka dengan orang yang diwawancarai.

c. Observasi

Observasi atau pengamatan merupakan salah satu teknik pengumpulan data primer dengan mengamati langsung suatu kegiatan yang sedang dilakukan.

\section{B. Pengembangan Sistem}

Metode pengembangan sistem yang digunakan adalah metode prototype, langkah-langkah dalam metode prototype adalah sebagai berikut:

\section{a. Pengumpulan Kebutuhan}

Untuk membangun komunikasi yang efektif diantara pengembang dan pelanggan. Pada tahap ini dilakukan dengan wawancara dengan pelanggan atau dengan pihak-pihak yang terkait mengenai sistem yang akan dirancang dan dijalankan nantinya. Tahap ini dengan tujuan untuk mendapatkan gambaran awal, sehingga pengembang mendapatkan sistem awal yang akan dikerjakan.

Pada tahapan ini dilakukan pengumpulan kebutuhan-kebutuhan diantaranya adalah :

a) Analisis Sistem Lama

Pada tahapan analisis sistem ini bertujuan untuk mengetahui sistem yang berjalan pada kemudian mendeskripsikannya sehingga dapat diketahui kelebihan dan kekurangannya.

b) Identifikasi Masalah Yang Dihadapi

Pendefinisian masalah merupakan tahapan yang dilakukan peneliti untuk menjawab dari permasalahan-permasalah yang sering terjadi dalam pemesanan menu makanan yag sedang berjalan pada saat ini.

c) Solusi Pemecahan Masalah

Pada tahapan ini penelitian memberikan usulan dalam penyelesaian masalah pada aplikasi pemesanan dengan menggunakan pendekatan sistem berbasis objek yaitu dengan menggunakan use case diagram, activity diagram, sequence diagram dan class diagram.

d) Kebutuhan Sistem

Pada tahapan ini bertujuan untuk merancang lingkungan dari sebuah sistem yang akan dibangun seperti penggunaan software, hardware dan operating sistem yang digunakan. Setelah kebutuhan penelitian terkumpul, kemudian dapat diambil sebuah kesimpulan untuk kebutuhan yang harus dipenuhi dalam membangun aplikasi pemesanan, kemudian pada langkah selanjutnya yaitu membangun prototype.

\section{b. Membangun Prototype}

Tahapan kedua ini tugas-tugas yang dibutuhkan untuk membangun sebuah prototype dari sebuah sistem yang akan dibangun meliputi :

\section{a) Perancangan Sistem Baru}

Pada tahapan ini bertujuan untuk merancang sistem baru, pada penelitian ini menggunakan notasi UML sebagai case tool dalam perekeyasaan perangkat sistem. Dari berbagai diagram UML yang ada beberapa yang digunakan dalam Prancangan sistem baru ini 


\section{c. Evaluasi Prototype}

Tahap evaluasi prototype ini dilakukan dengan tugas-tugas yang dibutuhkan untuk mengevaluasi prototype atas sistem yang diajukan kepada pelanggan untuk mendapatkan kesepakatan dalam perancangan sebuah sistem yang akan dibangun yang meliputi evaluasi dari segi manajemen maupun teknis dari sistem aplikasi.

Tahapan ini melakukan perancangan dan perbaikan terhadap sistem yang nantinya akan berjalan. Setelah evaluasi selesai kemudian pada langkah selanjutnya pada pengkodean sebuah sistem.

\section{d. Pengkodean Sistem}

Pada tahap ini tugas-tugas yang dibutuhkan untuk me-nerjemahkan suatu rancangan prototype yang sudah dievaluasi oleh user ke-bahasa pemrograman yang sesuai dengan penelitian dan pada penelitian ini bahasa pemrograman yang digunakan adalah Java, XML, PHP dan MySql sebagai databasenya.

\section{e. Pengujian Sistem}

Pada tahapan ini tugas-tugas yang dibutuhkan untuk mengkonstruksi, menguji,memasang (install) dan memberikan pelayanan kepada pemakai. Setelah pengkodean sistem dan sudah menjadi aplikasi pemesanan, apliaksi ini diuji dengan menggunakan dua cara diantaranya adalah sebagai berikut:

1) White Box Testing

Pengujian white box adalah pengujian suatu program sistem dari awal sampai akhir dan aliran data, apakah sudah sesuai atau belum dengan penelitian yang diharapkan.

2) Black Box Testing

Pengujian black box adalah pengujian aplikasi sistem yang melibatkan user, yang bertujuan untuk mengetahui segi kekurangan terhadap sistem aplikasi yang telah dibangun.

\section{f. Evaluasi Sistem}

Pada tahapan ini tugas-tugas yang akan dibutuhkan untuk memperoleh umpan baik dari pelanggan dengan didasarkan pada evaluasi representasi perangkat lunak, yang dibuat selama masa pengujian sistem. Pada tahapan ini merupakan tahap yang menentukan bahwa sistem ini sesuai atau tidak dengan keinginan pelanggan.

\section{g. Penggunaan Sistem}

Tahap selanjutnya adalah penggunaan sistem yang telah dibuat setelah evaluasi sistem selesai dan dinyatakan aplikasi pemesanan itu sesuai dengan yang diharapkan pelanggan.

\section{ANALISA DAN IMPLEMENTASI}

\section{A. Solusi Pemecahan Masalah}

Berdasarkan hasil analisa, maka bisa dirumuskan solusi seperti berikut:

1. Dapat dibangun suatu system yang menginformasikan harga bahan kebutuhan pokok (Sembako) secara riletime.

2. Pembeli dapat mengakses informasi harga menggunakan Handphone

3. Pemebeli dapat mengestimasikan uang yang akan dibawa untuk membeli sembako di pasar tradisional karawang.

4. Update harga yang dilakukan setiap minggu dapat membuat daftar harga menjadi tetap valid.

\section{B. Perancangan Sistem}

Pada tahapan ini bertujuan untuk merancang sistem baru, pada penelitian ini menggunakan use case diagram, activity daiagram dan sequence diagram.

\section{a. Use case Diagram}

se case mendeskripsikan sebuah interaksi antara satu atau lebih aktor dengan aplikasi yang akan dibuat, use case diagram pada perancangan sistem dapat dilihat pada gambar 4.2 di bawah ini : 


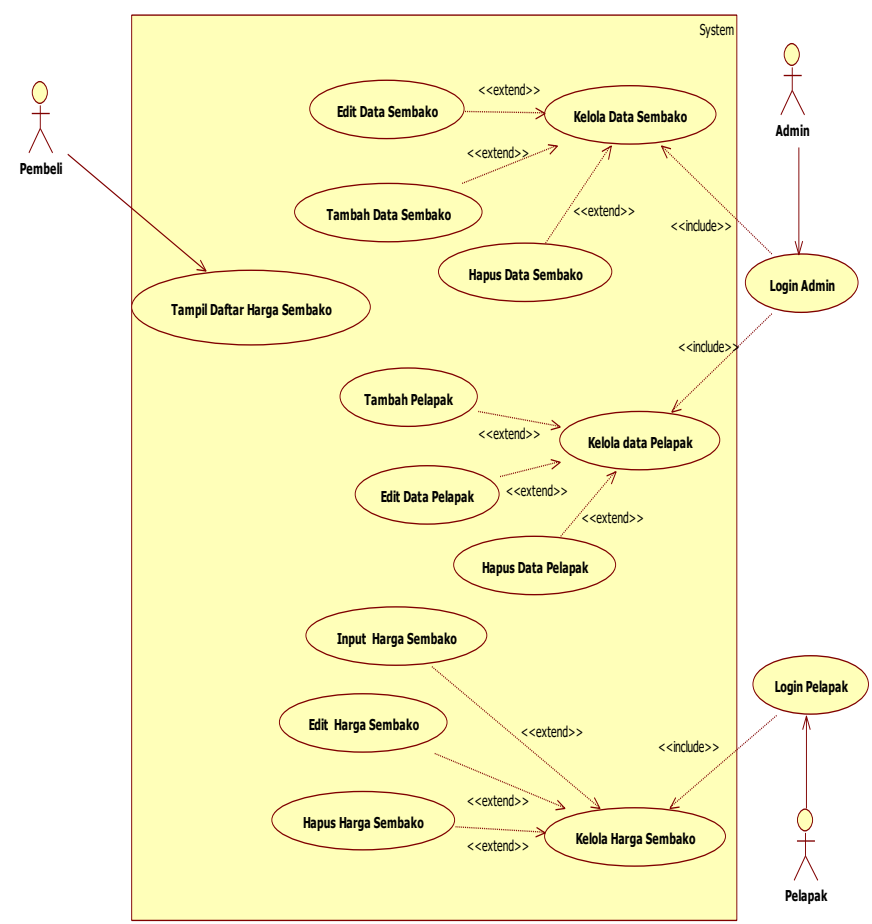

Gambar 4.1 Use Case Sistem Informasi Harga Sembako Dipasar Tradisional Karawang

\section{b. Activity Diagram}

Menggambarkan workflow (aliran kerja) atau aktivitas dari sebuah sistem atau proses bisnis. Yang perlu diperhatikan disini adalah bahwa aktivitas menggambarkan aktivitas sistem bukan apa yang dilakukan aktor, jadi aktivitas yang dapat dilakukan oleh sistem. Berikut adalah Activity Diagram Tampil Daftar Harga Sembako Aktifitas ini dilakukan oleh pembeli untuk melihat daftar harga pada system informasi harga harga kebutuhan pokok Activity Diagram ini dapat dilihat pada gambar 4.2 di bawah ini:

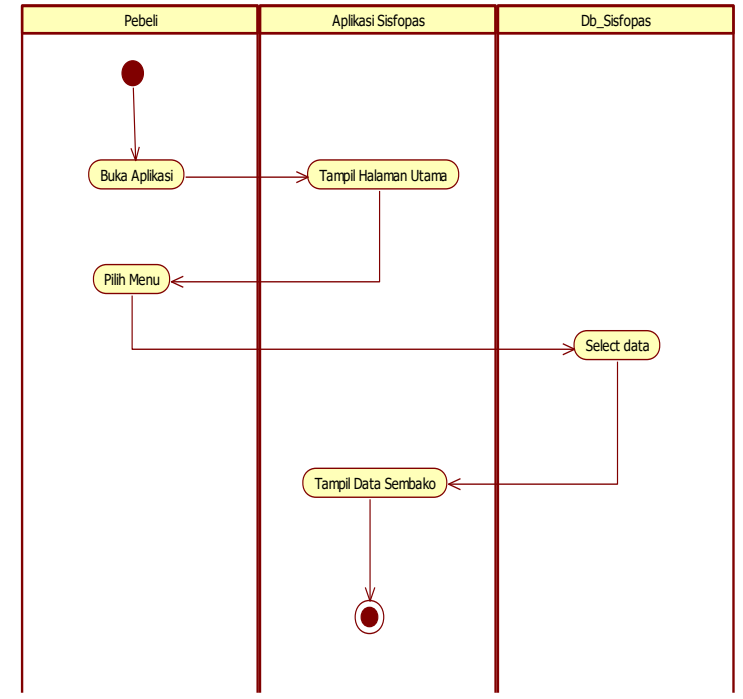

Gambar 4.2 Activity Diagram Tampil Daftar Harga Sembako

\section{c. Sequence Diagram}

Menggambarkan kelakuan objek pada use case dengan mendeskripsikan hidup objek dan message yang dikirimkan dan diterima antarobjek.Berikut merupakan Sequence Diagram Tampil Daftar Harga Sembako Sequence Diagram ini 
untuk melihat daftar harga sembako pada system informasi harga sembako di pasar tradisional karawang. Sequence Diagram ini dapat dilihat pada gambar 4.14 di bawah ini :

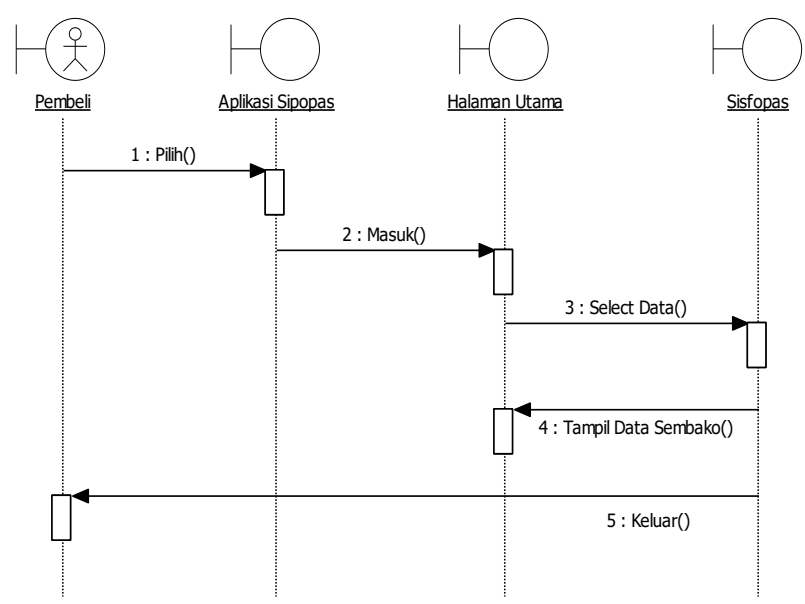

Gambar 4.3 Sequence Diagram Tampil daftar harga sembako

\section{Perancangan Database}

Perancangan database dilakukan setelah perancangan sistem, perancangan database yang dibuat terdiri dari class diagram.

\section{a. Class Diagram}

Class diagram berfungsi untuk struktur sistem dari pendefinisian kelas-kelas yang akan dibuat untuk membangun sistem. Berikut adalah class diagram untuk sistem informasi harga sembako:

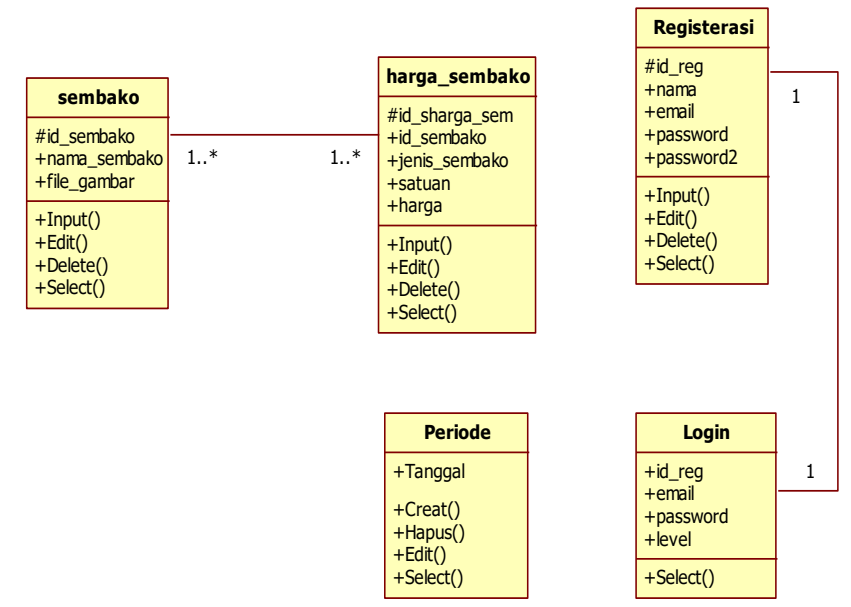

Gambar 4.4 Class diagram Sistem Informasi Harga Sembako

\section{Perancangan Interface}

Perancangan interface dalam sistem informasi harga bahan pokok. Berikut adalah desain untuk melihat daftar harga sembako bagi pembeli pada sistem informasi harga sembako pada pasar tradisional karawang. Rancangan ini dapat dilihat pada gambar 4.5 di bawah ini : 


\begin{tabular}{|c|c|}
\hline \multicolumn{1}{|c|}{ Go Market } \\
\hline \hline & \\
\hline Daftar Harga Sembako \\
\hline No & $\begin{array}{l}\text { Nama Sembako } \\
\text { Jenis Sembako } \\
\text { Satuan } \\
\text { Harga }\end{array}$ \\
\hline No & $\begin{array}{l}\text { Nama Sembako } \\
\text { Jenis Sembako } \\
\text { Satuan } \\
\text { Harga }\end{array}$ \\
\hline No & $\begin{array}{l}\text { Nama Sembako } \\
\text { Jenis Sembako } \\
\text { Satuan } \\
\text { Harga }\end{array}$ \\
\hline
\end{tabular}

Gambar 4.5 Desain Interface Daftar Harga Sembako

\section{Pengkodean Sistem}

Pada sub bab ini penelitian mengkonstruksi, menguji, memasang, dan memberikan pelayanan kepada pemakai. Jika seluruh obyek yang dibutuhkan telah selesai didesain maka tahap selanjutnya adalah mengkonstruksikan obyek-obyek yang telah selesai didesain ke dalam kode bahasa pemrograman. Berikut adalah tampilan melihat daftar harga

tampilan ini digunakan untuk melihat daftar harga sembako bagi pembeli pada sistem informasi harga sembako pada pasar tradisional karawang. Tampilan ini dapat dilihat pada gambar 4.6 di bawah ini :

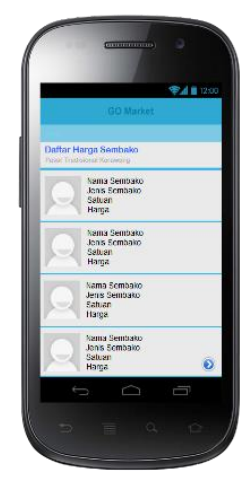

Gambar 4.6 Tampilan Program Daftar Harga Sembako

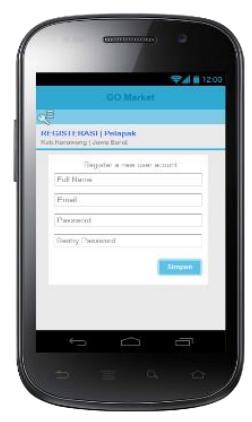


Gambar 4.7 Tampilan Form Registerasi Pelapak

\section{E. Pengujian Sistem}

Pengujian ini dilakukan untuk mendapatkan hasil yang maksimal dari aplikasi yang telah dibuat, maka perlu dilakukan pengujian terhadap aplikasi tersebut. Untuk mendapatkan hasil yang maksimal dari aplikasi yang telah dibuat, maka perlu dilakukan pengujian terhadap aplikasi tersebut. Untuk melakukan pengujian, dalam penelitian ini menggunakan metode pengujian Black-Box Testing dan White-Box Testing.

\section{a. White-Box Testing.}

Pengujian white box merupakan metode perancangan test case yang menggunakan struktur control dalam mendapatkan test case. Adapun metode yang digunakan dalam pengujian white box disini adalah metode base path. Metode base path mengijinkan pendesain kasus uji untuk mendapatkan perkiraan lojik yang kompleks dan menggunakan perkiraan ini untuk mendefenisikan aliran eksekusi.

\section{b. Black-Box Testing}

Merupakan sebuah metode yang digunakan untuk menemukan kesalahan dan mendemonstrasikan fungsional aplikasi saat dioperasikan, apakah input diterima dengan benar dan output yang dihasilkan telah sesuai dengan yang diharapkan. Untuk menguji masing-masing modul dalam sistem, maka diperlukan suatu pengujian.

\section{F. Evaluasi Sistem}

Agar aplikasi yang dirancang sesuai dengan keinginan pengguna maka aplikasi dievaluasi, berdasarkan wawancara dengan pembeli di pasar tradisioanal karawang, adapun pertanyaan yang disampaikan telah kami lampirkan.

Dasil dari wawancara tersebut kami ambil 200 sample pembeli dan 200 Penjual Sembako untuk diwawancarai.

\section{PENUTUP}

\section{A. Kesimpulan}

Berdasarkan penelitian yang telah dilaksanakan maka terdapat beberapa kesimpulan sebagai berikut :

1. Dalam mengumpulkan data harga sembako yang valid dilakukan kerjasama dengan dinas perdagangan daerah karawang, lalu petugas dapat menghimbau relawan pedagang dan stakeholder untuk berkontribusi dalam menginformasikan harga sembako kepada masyarakat melalui sistem yang telah dibangun.

2. Dengan membangun sistem informasi harga sembako di pasar tradisional karawang dengan menggunakan bahasa pemrograman Java, PHP, Sql serta dapat di terapkan pada platform Android. Dapat memberikan fungsi-fungsi yang mempermudah user dalam mengoprasikannya dan yang terpenting dapat memberikan manfaat untuk media penyampaian informasi harga sembako.

\section{B. Saran}

Berdasarkan hasil kesimpulan diatas, maka saran-saran yang dapat dikemukakan adalah :

1. Aplikasi yang dibangun masih sederhana sehingga dapat dilakukan pengembangan lebih lanjut seperti penambahan chart diagram harga sembako per-satu bulan, sehingga

masyarakat dapat mengetahui kenaikan dan penurunan harga sembako dengan mudah.

2. Masih terdapat beberapa pasar tradisional yang belum terdaftar pada sistem informasi harga sembako.

\section{REFERENSI}

[1] Al-Bahra Bin Ladjamudin (2005). Analisis dan Desain Sistem Informasi. Yogyakart : Graha Ilmu.

[2] Eddy Afrianto, dkk (2008), Pengawasan Mutu Bahan/Produk Pangan. Jakarta : Direktorat Pembinaan Sekolah Menengah Kejuruan

[3] Gilbran Imami (2015), Aplikasi pada Perangkat Mobile untuk Mendukung Penulisan Program, Jurnal TI. Bandung

[4] Janner Simarmata (2010). Rekayasa Perangkat Lunak. Yogyakarta : C.V Andi Offset.

[5] Marcelina Rizka Falevy dkk (2012). Sistem Peramalan Harga Sembako Berbasis Moving Average Dengan Brew Platform Sebagai Mobile Interfaces. Surabaya. 
[6] M. Shalahuddin, Rosa A.S. (2010). Java di Web. Bandung : Informatika.

[7] Murya Arief Basuki, (2009), Analisa Website Universitas Muria Kudus, Jurnal Sains, Vol.2 No.2, 2009.

[8] Nazruddin Safaat H (2012). Program Aplikasi Mobile Smartphone dan Tablet PC Berbasis Android. Bandung : Informatika.

[9] Suparto Darudiato dkk (2006). Analisis Dan Perancangan Basis Data Eksplorasi Berbasis Objek Studi Kasus Kondur Petroleum SA. PT.UPS : Jiurnal SNATI.

[10] Utami Dewi dan F. Winarni (2014). Pengembangan Pasar Tradisional Menghadapi Gempuran Pasar Modern di Kota Yogyakarta. Jurnal Akutansi Negara. Yogyakarta

[11] Wahyu Lukman Hakim (2011). Prototyping Model. http://id.scribd.com/doc/58298607/ Pengertian-Prototype (18-01-2016, 02.00).

[12] Jogiyanto H.M, Analisis \& Desain, Yogyakarta, C.V Andi Offset, (2005). 